\title{
Big cats are still walking in El Salvador: first photographic records of Puma concolor (Linnaeus, 1771) and an overview of historical records in the country
}

\author{
Andrea Morales-Rivas ${ }^{1}$, Francisco S. Álvarez ${ }^{2,3}$, Xochilt Pocasangre-Orellana $^{3}$, Luis Girón ${ }^{4}$, \\ Gloria N. Guerra ${ }^{5}$, Reynaldo Martínez ${ }^{5}$, Juan Pablo Domínguez ${ }^{6}$, Franz Leibl ${ }^{7}$, Christoph Heibl $^{7}$
}

1 Institute of Botany and Landscape Ecology, University of Greifswald, Grimmer Str. 88, 17487 Greifswald, Germany. 2 UDP Ciencias Neotropicales, Departamento de Investigación, Calle Francisco Campos 166, Colonia Escalón, CP 1101, San Salvador, El Salvador. 3 Fundación Naturaleza El Salvador, Departamento de Investigación, Colonia Escalón, CP 1101, San Salvador, El Salvador. 4 Asociación Territorios Vivos El Salvador, Colonia Vista Hermosa, calle Las Acacias \#120, San Salvador, El Salvador. 5 Parque Nacional Montecristo, Cantón San José Ingenio, Municipio de Metapán, Santa Ana, El Salvador. 6 BioSistemas Network, Calle Las Acacias 120, Colonia Vista Hermosa. San Salvador, El Salvador. 7 Bavarian Forest National Park, Freyunger Str. 2, 94481 Grafenau, Germany.

Corresponding author: Andrea Morales-Rivas, moralesae14@gmail.com

\begin{abstract}
The presence of Puma, Puma concolor, has been controversial in El Salvador due to the lack of published, verifiable data. We surveyed 119 sites in Montecristo National Park and 17 sites in the Río Sapo basin using wildlife cameras. We detected Pumas in both areas, representing the first photographic records for El Salvador. We call for a national Puma conservation strategy with research in basic ecology and migration corridors, regulation of hunting, management of livestock losses, and public acceptance programs. The Río Sapo basin should be granted formal protection.
\end{abstract}

\section{Keywords}

Camera trap, cougar, Central America, distribution, mammals, Montecristo, Río Sapo.

Academic editor: Diego Astúa | Received 5 December 2019 | Accepted 1 April 2020 | Published 13 May 2020

Citation: Morales-Rivas A, Álvarez FS, Pocasangre-Orellana X, Girón L, Guerra GN, Martínez R, Domínguez JP, Leibl F, Heibl C (2020) Big cats are still walking in El Salvador: first photographic records of Puma concolor (Linnaeus, 1771) and an overview of historical records in the country. Check List 16 (3): 563-570. https://doi.org/10.15560/16.3.563

\section{Introduction}

The Puma, Puma concolor (Linnaeus, 1771), is the most widespread felid in the American continent, present in more than 20 countries (Nielsen et al. 2015) and found in a variety of habitats across an elevation range from sea level to $5,800 \mathrm{~m}$. In spite of its large distribution range from the Canadian Rocky Mountains to the Strait of Magellan (Sunquist and Sunquist 2002; Nielsen et al. 2015), the Puma is threatened by destruction and fragmentation of its habitat. Mortalities from vehicle collisions (road-kills) also constitute a threat for the species (da Silva et al. 2014; USFWS 2014; Nielsen et al. 2015). In livestock areas, especially in Latin America, they are persecuted and killed indiscriminately (Hunter 2015), mainly due to human fear or occasional depredation of cattle (Campbell and Torres-Alvarado 2011). In Central America, habitat use, behavior, demography, and reproduction are poorly known (Soto-Shoender and Giuliano 2011; Campbell 2016), which makes it difficult 
to establish conservation actions (Laundré and Hernán$\operatorname{dez} 2010)$.

In 1942, a skull and partial skeleton (MVZ 98310) were found near Lake Olomega, Department of San Miguel in southeastern El Salvador. This provided the first scientific record of Puma concolor in the country (Burt and Stirton 1961). To our knowledge, no other verifiable Puma record has been documented since (e.g. scientific collections in museums, photographs). The lack of published Puma records in recent years, combined with the isolation of forests in El Salvador and their limited connection with other biological corridors in Central America (Campbell 2016), led some researchers to believe that Pumas were extinct in El Salvador (e.g. Campbell and Torres 2011). However, Campbell (2016: 2) also admitted that the "very adaptability [of Pumas] makes conclusions about its extinction difficult." The potential persistence of the Puma in El Salvador has been suggested by occasional sightings and tracks reported by the rural population and some local research, for example, an institutional report of a Puma killed by hunters in the northeast of the department of Morazán (Juan Pablo Domínguez, pers. obs.). Owen and Girón (2012) summarized some of these records found between 1984 and
2006 with nationwide distribution (Fig.1; Appendix). To move a step forward in Puma conservation, we need hard evidence about its occurrence to guide management and research plans, and effective communication with stakeholders and decision-makers. Here we present the first photographic records of Puma concolor in El Salvador obtained by two independent camera-trapping projects and discuss their bearing on research and conservation of the country's largest carnivore.

\section{Methods}

In the middle of the rainy season 2018 and the beginning of the dry season 2019, two independent wildlife observation and monitoring projects began deployment of wildlife cameras in northeastern and northwestern El Salvador, respectively. The first wildlife observation project was carried out on privately-owned land $(\approx 6,000$ ha) with the support of volunteers and forest owners in the Río Sapo basin area in the department of Morazán. This region is characterized by a decrease in agricultural and livestock activities in the last decades replaced by the receipt of remittances from family members in foreign countries, which has led to an increase in forest

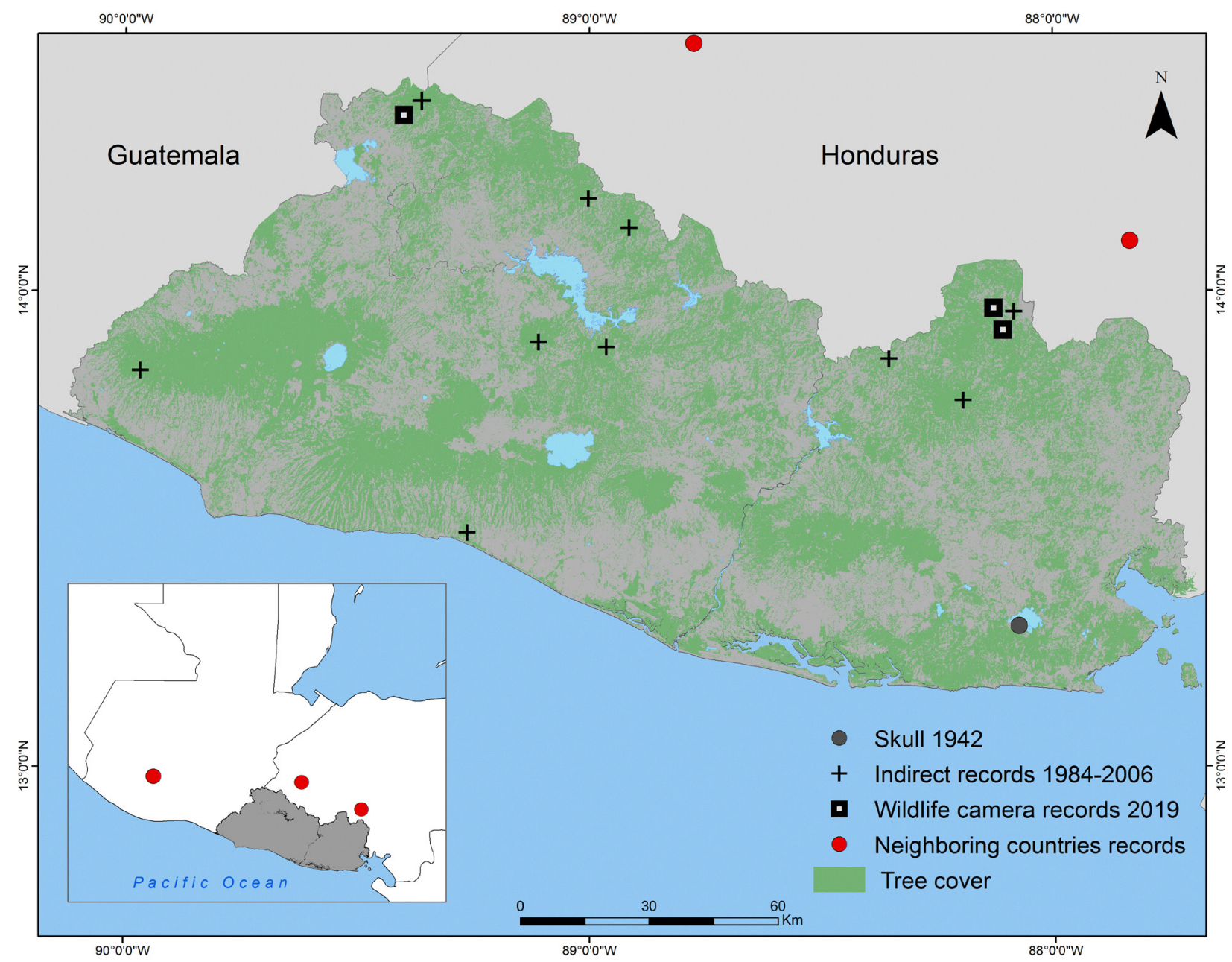

Figure 1. Historical and new records of Puma concolor in El Salvador including nearby records from Guatemala and Honduras. Crosses represent historical records based on sightings, tracks, scats, and a lost skull. Squares represent photographic records from wildlife cameras during 2019. Red circles are the closest Puma records from Guatemala and Honduras. Tree cover was extracted from Hansen et al. (2013). 
coverage between 1992 and the beginning of the 2000s (Hecht et al. 2006; Hecht and Saatchi 2007). However, despite the increase in forest coverage in this region, forests are currently under pressure from logging and illegal trade resulting from a lack of protection. The second project took place in Montecristo National Park in the department of Santa Ana. With an extent of 1,973 ha, it represents one of the largest terrestrial protected areas in the country (MARN 2018). At present, poaching and land-use changes in the surroundings of the national park, the so-called "buffer zone", are threatening species and ecosystems in the area.

In the Río Sapo basin, 17 locations with a minimum separation distance of $300 \mathrm{~m}$ were chosen according to evidence of wildlife activity. In this project, nine cameras of different models were used (Cabela's, Bushnell, and CamPark), and the location of the cameras were changed every 20 days, approximately. In Montecristo, we placed wildlife cameras (Cuddeback C-123) individually at each site (one camera per site), sampling 119 locations in a random stratified sampling design giving equal weight to different habitat types. The camera locations were placed at least $200 \mathrm{~m}$ from each other and $100 \mathrm{~m}$ from the border of the national park. Local topography in the two study areas is mountainous with permanent and seasonal streams and ravines. The climate is tropical, with a well-defined dry season from November to April and a rainy season from May to October.

\section{Results}

We obtained six Puma records. One record was in a tropical semi-deciduous mixed lower montane forest (Vreugdenhil et al. 2012) in Montecristo National Park, and five were in a tropical semi-deciduous mixed submontane forest (Vreugdenhil et al. 2012) in Río Sapo basin with a total sampling effort of 3570 and 2520 camera trap-days, respectively.

New records. EL SALVADOR • 1; Department of Santa Ana, Montecristo National Park; $14^{\circ} 23^{\prime} 19.90^{\prime \prime} \mathrm{N}, 089^{\circ}$ 23'14.86"W; $1511 \mathrm{~m}$ a.s.1.; 6 Mar. 2019; Montecristo project leg.; photographed at 07:20h; after 15 trap nights; wildlife camera; Figure 2A. • 1; Department of Morazán, Río Sapo basin; $13^{\circ} 56^{\prime} 06.70^{\prime \prime} \mathrm{N}, 088^{\circ} 06^{\prime} 01.62^{\prime \prime} \mathrm{W} ; 705 \mathrm{~m}$ a.s.l.; 5 Apr. 2019; Río Sapo basin project leg.; photographed at 23:59h; after 9 trap nights; wildlife camera; Figure 2B. • 1 సं; Department of Morazán, Río Sapo basin; $13^{\circ} 56^{\prime} 18.94^{\prime \prime} \mathrm{N}, 088^{\circ} 06^{\prime} 02.42^{\prime \prime} \mathrm{W} ; 716 \mathrm{~m}$ a.s.1; 22 Jul. 2019; Río Sapo basin project leg.; video recorded and photographed at 19:21h; after 19 trap nights; Figure 2C • 1; same data as for preceding; 25 Aug. 2019; Río Sapo basin project leg.; video recorded and photographed at 19:22h; after 10 hours of camera placement; wildlife camera; Figure 2D. • 1; Department of Morazán, Río Sapo basin; 1356'08.71"N, 08806'01.61”W; 706 m a.s.1.; 21 Sep. 2019; Río Sapo basin project leg.; photographed at 22:00h; wildlife camera; Figure $2 \mathrm{E} \bullet 1$; same

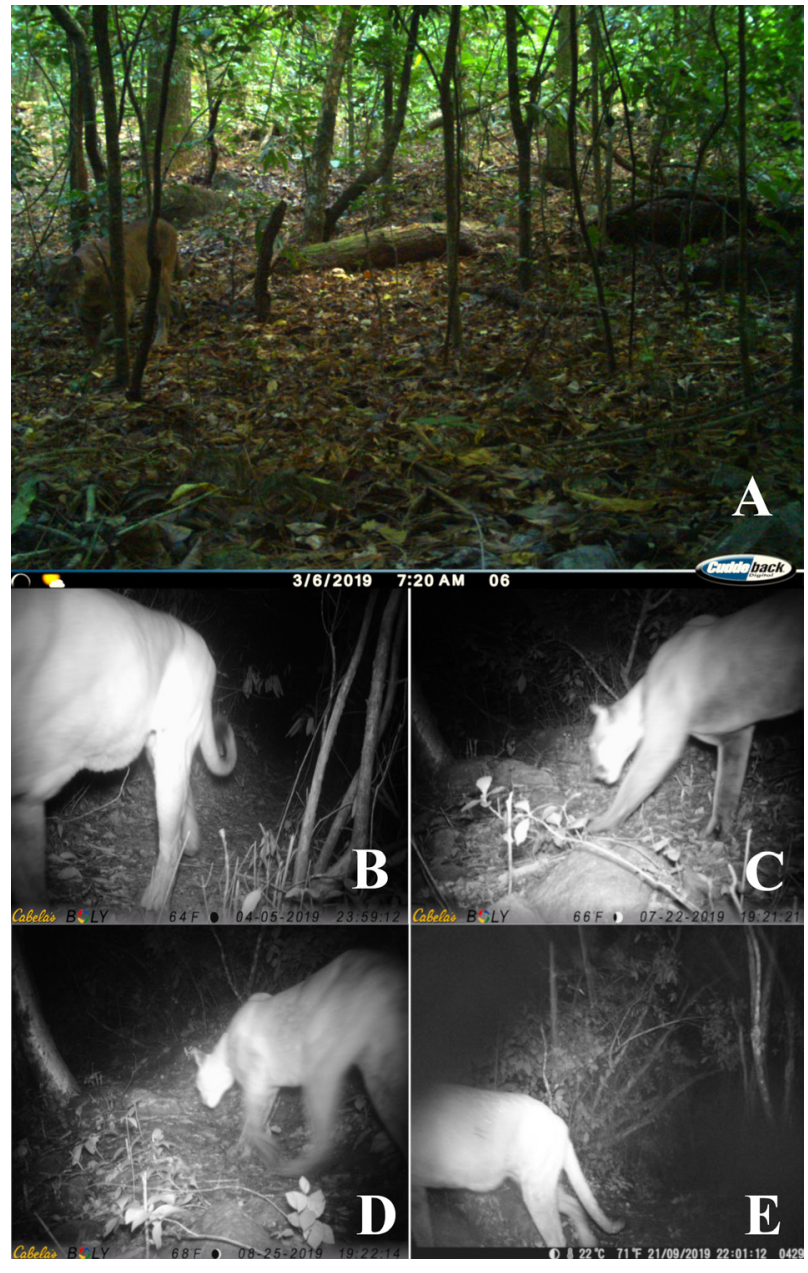

Figure 2. Photographic records of Puma concolor in two departments of El Salvador. A. From Montecristo National Park, Santa Ana, El Salvador. B. From Río Sapo basin, Morazán, El Salvador. C. Male, from Río Sapo basin, Morazán, El Salvador. D. From Río Sapo basin. E. From Río Sapo basin.

data as for preceding; 30 Oct. 2019; Río Sapo basin project leg.; photographed at 02:59h; after 11 trap nights; wildlife camera.

Identification. We identified the species as Puma concolor for its external characteristics, which easily differentiate them from other cats in the region: unspotted fur in juveniles and adults, a light grayish brown color, large body size, and the tip of the tail is dark brown or black (Currier 1983, Reid 2009). The sex determination of the male from Río Sapo basin was via observation of testicles, which were visible in the video recorded in July 2019.

\section{Discussion}

Little is known about the Puma in El Salvador. Given the country's reputation for degraded ecosystems and overpopulation (Dull 2008), to some, it seemed unlikely that top predators like the Puma could have survived in El Salvador (Campbell 2016). All the more exciting is the detection of Puma concolor by two independent camera trapping studies within a short period of time. 
The photos and videos from Montecristo and Río Sapo basin presented in this note are the first Puma detections by wildlife cameras in El Salvador, 72 years after the first official record of a Puma near Lake Olomega (MVZ 98310, Burt and Stirton 1961). Due to the high cost and lack of expertise, camera trapping has only recently attracted attention in El Salvador. These findings are, therefore, an important local demonstration of the method's well-known efficiency in detecting rare and elusive species. Their unspotted fur, variable physical conditions, and geographic variation make the identification of identity, age, or sex in Puma based on photography alone difficult and unreliable (Rahel Sollmann pers. comm.), especially if no references are available as it is the case in El Salvador. In addition, individual markings (e.g. scars) are not visible on our photos. Consequently, our results are consistent with the presence of either one, two, or three individuals of Puma concolor between March and October 2019 in El Salvador.

It is apparent that Pumas still find suitable habitat in El Salvador. Even if we assume that we captured only migrating individuals, our findings imply that the habitats qualify at least as dispersal corridors and suggest some level of ecosystem health (Winnie and Creel 2017; Barry et al. 2019). It is difficult to judge whether they also allow for the permanent establishment of Pumas, i.e., offer suitable habitat of adequate size and prey abundance (Núñez et al. 2000; Polisar et al. 2003), especially given the sparse knowledge about the ecology of Puma in Central America (Laundré and Hernández 2010). Habitat use by Pumas in Central America has been studied in Panama (Craighead 2019), Belize (Foster et al. 2010; Davis et al. 2011), Guatemala (Hernández 2008), and Mexico (adjacent to Guatemala: de la Torre et al. 2017; adjacent to Belize: Ávila-Nájera et al. 2018a). It is often stated that Pumas can adapt to human-dominated landscapes because of their wide ecological niche, both in habitat use and prey diversity (Núñez et al. 2000; Knopff et al. 2014; Moss et al. 2016). However, habitat modeling based on camera trapping data estimates primary forest as the most important variable for Puma habitat selection in Panama, particularly in the dry season (Craighead 2019). In tropical forests on the Yucatán Peninsula, studied in Belize and Mexico (Quintana Roo), Pumas tend to react negatively to human presence inside (Davis et al. 2011; Ávila-Nájera et al. 2018a) and outside protected areas (Foster et al. 2010). The exact mechanisms that underlie human impacts on Puma space use might be a complex interaction between vegetation structure, prey abundance, and human behavior. As such Zanin et al. (2015) recommend dedicated theory-driven modeling approaches to understand the consequences of habitat loss and fragmentation.

Information about the dietary habits of Puma in Central America is available only from Costa Rica (Bustamante et al. 2014), Belize (Foster et al. 2010), Guatemala (Novack et al. 2005; Hernández 2008), and Mexico (Yucatán peninsula, near the border of Belize;
Ávila-Nájera et al. 2018b). Together, these studies suggest that Central American Pumas favor prey with body weights between 3.5 and $45 \mathrm{~kg}$. White-tailed deer Odocoileus virginianus (Zimmerman, 1780), South American Red Brocket Mazama americana (Erxleben, 1777), Collared Peccary Pecari tajacu (Linnaeus, 1758), White-lipped Peccary Tayassu pecari (Link, 1795), some rodents like Lowland Paca Cuniculus paca (Linnaeus, 1766), and Central American Agouti Dasyprocta punctata (Gray, 1842) make up the main part of prey found in scat analyses. To a lesser extent, Pumas chose Whitenosed Coati Nasua narica (Linnaeus, 1766), and Ninebanded Armadillo Dasypus novemcinctus (Linnaeus, 1758), the latter apparently gaining importance in more arid habitats (Monroy-Vilchis et al. 2009). Birds (Tinamuformes, Galliformes) and reptiles are only occasionally fed upon. Except for T. pecari (extirpated or possibly extirpated in El Salvador), all these species represent potential prey species in El Salvador. Based on our camera trapping data from Montecristo, O. virginianus, $D$. novemcinctus, D. punctata, and $N$. narica represent the most abundant species of medium to large ground-dwelling mammals. However, there is evidence of illegal hunting of these potential prey species (Morales-Rivas 2019, unpublished data). Hence, whether the absolute prey density in Montecristo National Park is enough to support resident Pumas remains an open question. Even less can be said about the situation outside protected areas, as we are not aware of any studies, which quantify prey densities across gradients of human disturbance or formal protection. The situation is similar in the Río Sapo basin, where camera trap records show the presence of species such as $O$. virginianus, $C$. paca, and D. punctata on several occasions. These species likely form part of Puma's diet, although information about these prey populations is uncertain. In the case of the Río Sapo basin, forest owners report illegal wildlife hunting of mainly $O$. virginianus and $C$. paca, which could generate competition between Pumas and humans in their prey selection.

Our study areas are near the borders of Honduras and Guatemala. The closest records of Pumas in Honduras are from Celaque National Park and from Guajiquiro Nature Reserve (Marineros and Martínez 1998) with linear distances of $71 \mathrm{~km}$ to Montecristo and 32 $\mathrm{km}$ to Río Sapo basin, respectively. Given an estimated mean dispersal distance of $70 \mathrm{~km} \pm 16 \mathrm{~km}$ (GonzalezBorrajo et al. 2017), connectivity between our sites and the population of western Honduras is possible assuming the presence of suitable dispersal corridors. Less likely is the connection with the closest records of Pumas in the private nature reserves of the Sierra Madre de Chiapas (Escobar-Anleu et al. 2017) given both the isolation (linear distances of approx. $190 \mathrm{~km}$ ) and the massive changes in forest cover in south-western Guatemala (López-Carr et al. 2012). Crespin and García-Villalta (2014) identify the connectivity of suitable habitats across borders as one of the key factors required for a viable Puma population in El Salvador. They base their argument on the 
discrepancy between Puma's home range sizes (37-755 $\mathrm{km}^{2}$, Gonzalez-Borrajo et al. 2017) and the small size of protected areas that this small and densely populated country can spare. In this sense, the Trifinio Fraternidad Transboundary Biosphere Reserve (TFTBR), a trinational biosphere reserve located between El Salvador, Guatemala, and Honduras (UNESCO 2016), is a promising example as the first step towards a reconditioning of the Mesoamerican Biological Corridor (MBC) (Crespin and Garcia-Villalta 2014). The MBC is a transnational planning system, which was established in 1997 with the intention of reconciling biodiversity conservation and rural development in southern Mexico and Central America (CCAD 2002; Crespin and Garcia-Villalta 2014). It has since been criticized for "moving away from its core goal of biodiversity preservation" (Dettman 2006). Following the example of the TFTBR, the establishment of a transboundary protected area between the Río Sapo basin and the suitable habitats in Honduras, e.g., the Guajiquiro Nature Reserve, could foster a dispersal corridor for Pumas between El Salvador and Honduras.

Tightly linked with the question of connectivity is the mortality from vehicle collision, often referred to as road-kills. In Latin America, the systematic investigation of road-kill has only recently been started (da Silva et al. 2014; Grilo et al. 2018), driven by concerns about the ecological impact of road network upgrading in Brazil. In El Salvador, no road-kill of a Puma has been registered so far, nor is there any systematic assessment of road-kill related to any mammal species. We can only speculate if the absence of Puma mortalities due to road traffic in El Salvador is caused by the species' low densities, the low density of the road network in regions where Pumas are likely to occur, a lack of systematic study, or a combination thereof. It is clear, though, that the avoidance of road-kill should be part of any national conservation strategy (see below) and rural development scheme.

What does the presence of Puma concolor imply for research and conservation in El Salvador? It is obvious that there are large knowledge gaps regarding the ecology of Central American Pumas, which makes it difficult to propose detailed management actions. However, seven recommendations can be given immediately:

1. Basic ecological research. The disentanglement of the effects of habitat structure, prey diversity, and human behavior in driving Puma space use requires high-quality data and modern modeling approaches. Satellite telemetry, camera trapping, and meta-barcoding provide these high-quality data but are expensive and require specialized skills. For these reasons, we suggest international teams design and carry out this research in the framework of the MBC, not least because the resulting management implications are also likely to be transnational.

2. Developing a national Puma conservation strategy. El Salvador needs to (a) gather and curate Pumarelated data, (b) develop a long-term strategy for Puma conservation, and (c) start projects to implement the measures suggested by the strategy. We advise the creation of a monitoring program covering the country's Conservation Areas (MARN 2019), prioritizing those with historical and contemporary Puma records. The support for the management entities in charge of protected areas and wildlife with the required knowledge and tools is crucial. The initial step would be to estimate a map of Puma occupancy for El Salvador for further conservation planning. This information can be supplemented by the collection of opportunistic data, which can be useful when classified according to trustworthiness (see the example of "SCALP criteria" in Magg et al. 2016). To prioritize conservation actions and projects, a detailed threat assessment for the Puma in the country would be useful.

3. Connectivity. In the highly fragmented territory of El Salvador, the successful dispersal and genetic exchange of Pumas will depend critically on the availability of suitable dispersal corridors. Hence, we propose a GIS-based analysis of landscape features to identify potential dispersal corridors in El Salvador and across borders into adjacent countries. The proposed corridors should be optimized by land use planning, legally protected, and their efficiency monitored. All these measures could be implemented using existing tools and experience of the MBC. As El Salvador develops, the expansion of the road network and increased traffic will call for a strategy to mitigate road traffic mortalities.

4. Regulation of hunting. In anthropogenic landscapes, but also many protected areas, Pumas must compete with human hunters for wild animal prey. To avoid Pumas switching to domestic animals, adequate densities of wild prey species must be present. To this end, Foster et al. (2010) proposed hunting regulation, particularly of ungulates and pacas. Such regulations can gain acceptance by embedding them in wildlife co-management programs (Berkes 2009). Of course, hunting regulations only make sense if the authorities are willing and able to curtail poaching.

5. Dealing with livestock losses. There is certain albeit low probability of domestic animal depredation by Pumas. One way to mitigate this problem is the introduction of a compensation payment scheme, where the right to compensation is tied to the proper protection of domestic animals with fences, dogs, or mixing with species that show anti-predator behavior (e.g. water buffalos). Smallholders should obtain subsidies when necessary because they often lack resources for adequate protection measures. International NGOs and development aid organizations might be willing to help launch a fund for the compensation payment scheme. Compensation for livestock losses might also be achieved by generating alternative income opportunities (Crawshaw 2003), this could be realized with, for example, ecotourism (Laundré and Hernández 2010). Some countries, such as Costa Rica, have welldeveloped ecotourism programs, which could serve as 
a model for countries like El Salvador (Laundré and Hernández 2010).

6. Raising public acceptance. Asked about their attitude towards the Puma, people in El Salvador opted more for toleration or removal than shooting (Campbell and Torres-Alvarado 2011), which is not a bad initial position. The goal will be to raise public awareness of the ecological role of large predators with attractive environmental education programs in schools, protected areas, and rural communities (Conforti and Azevedo 2003; Laundré and Hernández 2010). In regions where Pumas are expected or known to exist, these programs must be supplemented by regular workshops in rural communities that help people resolve the issues that arise while living together with the Puma.

7. Grant formal protection to the Rio Sapo basin. Poaching, land-use changes, illegal trade, logging, and uncontrolled tourism threaten ecosystem integrity in the Río Sapo basin. The conservation and protection of the Río Sapo basin could sustain populations of many species including large predators such as the Puma. Therefore, guaranteeing the conservation of one of the critical habitats for local and regional biodiversity (Brauneder et al. 2018) would be advantageous, and would even represent the largest protected area in El Salvador.

\section{Acknowledgments}

Authors wanted to thank Jörg Müller, Marco Heurich, Martin Gahbauer, Maik Hendrich, and Joe Premier (Bavarian Forest National Park) and Guanacaste Wildlife Monitoring for their technical support in Montecristo and Río Sapo basin, respectively. We also thank Anastely Mártir and the rangers Vidal P. Martínez, Saúl García, and Guillermo Matute, who took part in the fieldwork in Montecristo National Park, and all forest owners at Río Sapo basin, which allowed us to access their lands. Also, we owe thanks to Lety Méndez, Jürgen Tönnesen, Maritza Guido, Fausto Elvir, Julio César Pereira Hernández, Jesús Chica Pereira, José Argueta Rivera, Erwin Chica Argueta, Hermes López, José Argueta Romero, and Mercedes Chicas for their collaboration. Lucas Gonçalves da Silva and two anonymous reviewers provided comments that improved the paper. The camera trapping project in Montecristo Nacional Park was carried out in partnership with the Bavarian Forest National Park, Germany, and was funded by the Bavarian State Ministry of the Environment and Consumer Protection.

\section{Authors' Contributions}

AMR, CH, FA, and LG coordinated the fieldwork and sampling design. AMR, FA, GG, XPO, RM, LG and JPD conducted fieldwork. FL found financing for Montecristo project. FA and JPD found financing for Río Sapo project. AMR and $\mathrm{CH}$ wrote the manuscript; all authors reviewed the manuscript.

\section{References}

Ávila-Nájera DM, Chávez C, Pérez-Elizalde S, Guzmán-Plazola RA, Mendoza GD, Lazcano-Barrero MA (2018a) Ecology of Puma concolor (Carnivora: Felidae) in a Mexican tropical forest: adaptation to environmental disturbances. Revista de Biología Tropical 66 (1): 78-90. https://doi.org/10.15517/rbt.v66i1.27862

Ávila-Nájera DM, Palomares F, Chávez C, Tigar B, Mendoza GD (2018b) Jaguar (Panthera onca) and puma (Puma concolor) diets in Quintana Roo, Mexico. Animal Biodiversity and Conservation 41 (2): 257-266. https://doi.org/10.32800/abc.2018.41.0257

Barry JM, Elbroch LM, Aiello-Lammens ME, Sarno RJ, Seelye L, Kusler A, Quigley HB, Grigione MM (2019) Pumas as ecosystem engineers: Ungulate carcasses support beetle assemblages in the Greater Yellowstone Ecosystem. Oecologia 189 (3): 577-586. https://doi.org/10.1007/s00442-018-4315-z

Berkes, F (2009) Evolution of co-management: Role of knowledge generation, bridging organizations and social learning. Journal of Environmental Management 90 (5): 1692-1702. https://doi.org/ 10.1016/j.jenvman.2008.12.001

Brauneder, KM., Montes C, Blyth S, Bennun L, Butchart SHM, Hoffmann M, Burgess ND, Cuttelod A, Jones MI, Kapos V, Pilgrim J, Tolley MJ, Underwood EC, Weatherdon LV, Brooks SE (2018) Global screening for Critical Habitat in the terrestrial realm. PloS ONE 13 (3): e0193102. https://doi.org/10.1371/journal.pone. 0193102

Burt WH, Stirton RA (1961) The mammals of El Salvador. Publications of the Museum of Zoology, University of Michigan 117: $1-69$.

Bustamante A, Moreno R, Rossel EA, Artavia A (2014) Depredación del Puma (Puma concolor) en un bosque neotropical centroamericano. Revista Latinoamericana de Conservación 4 (1): 40-45.

Campbell MO, Torres-Alvarado M (2011) Public perceptions of jaguars Panthera onca, pumas Puma concolor and coyotes Canis latrans in El Salvador. Area 43 (3): 250-256. https://doi.org/10.1111/ j.1475-4762.2011.00996.x

Campbell MO (2016) The factors for the extinction of jaguars and cougars in El Salvador. Journal of Biodiversity, Bioprospecting and Development 3 (1): 1-7. https://doi.org/10.4172/23760214.1000154

CCAD (Central American Commission on Environment and Development) (2002) El Corredor Biológico Mesoamericano: Una plataforma para el desarrollo sostenible regional. Serie Técnica 01, Proyecto para la Consolidación del Corredor Biológico Mesoamericano, Managua, Nicaragua, 24 pp.

Craighead KA (2019) A multi-scale analysis of jaguar (Panthera onca) and Puma (Puma concolor) habitat selection and conservation in the narrowest section of Panama. PhD Thesis, Antioch University New England, Keene, New Hampshire, 179 pp.

Crawshaw, PG Jr (2003) A personal view on the depredation of domestic animals by large cats in Brazil. Natureza Conservacao 1: 71-73.

Crespin SJ, García-Villalta JE (2014) Integration of land-sharing and land-sparing conservation strategies through regional networking: The Mesoamerican Biological Corridor as a lifeline for carnivores in El Salvador. Ambio 43 (6): 820-824. https://doi. org/10.1007/s13280-013-0470-y

Conforti VL, Azevedo FCC (2003) Local perceptions of jaguars Panthera onca and pumas Puma concolor in the Iguacu National Park area south Brazil. Biological Conservation 111 (2): 215-221. https://doi.org/10.1016/S0006-3207(02)00277-X

Currier MJP (1983) Felis concolor. Mammalian Species: 1-7. https:// doi.org/10.2307/3503951

Davis ML, Kelly MJ, Stauffer DF (2011) Carnivore co-existence and habitat use in the Mountain Pine Ridge Forest Reserve, Belize. Animal Conservation 14 (1): 56-65. https://doi.org/10.1111/j. 1469-1795.2010.00389.x

Dettman S (2006) The Mesoamerican Biological Corridor in Panama 
and Costa Rica: integrating bioregional planning and local initiatives. Journal of Sustainable Forestry 22 (1-2): 15-34. https://doi org/10.1300/J091v22n01_02

Dull RA (2008) Unpacking El Salvador's ecological predicament: Theoretical templates and "long-view" ecologies. Global Environmental Change 18 (2): 319-329. https://doi.org/10.1016/j.gloenv cha.2008.03.002

Escobar-Anleu BI, Fuentes-Montejo CE, Ariano-Sánchez D (2017) Registros de mamíferos (Mammalia: Didelphimorphia, Artiodactyla, Carnivora, Cingulata, Lagomorpha, Pilosa y Rodentia) en reservas naturales privadas de Guatemala. Acta zoológica mexicana 33(2): 389-393. https://doi.org/10.21829/azm.2017.3321077

Foster RJ, Harmsen BJ, Doncaster CP (2010) Habitat use by sympatric Jaguars and Pumas across a gradient of human disturbance in Belize. Biotropica 42 (6): 724-731. https://doi.org/10.1111/j.1744 7429.2010.00641.x

Gonzalez-Borrajo N, López-Bao JV, Palomares F (2017) Spatial ecology of jaguars, pumas, and ocelots: a review of the state of knowledge. Mammal Review 47 (1): 62-75. https://doi.org/10.1111/mam. 12081

Grilo C, Coimbra MR, Cerqueira RC, Barbosa P, Dornas RAP, Gonçalves LO, Teixeira FZ, Coelho IP, Schmidt BR, Pacheco DLK, Schuck G, Esperando IB, Anza JA et al. (2018) Brazil road-kill: a data set of wildlife terrestrial vertebrate road-kills. Ecology 99 (11): 2625. https://doi.org/10.1002/ecy.2464

Hansen MC, Potapov PV, Moore R, Hancher M, Turubanova SA, Tyukavina A, Thau D, Stehman SV, Goetz SJ, Loveland TR, Kommareddy A, Egorov A, Chini L, Justice CO, Townshend JRG (2013) High-resolution global maps of 21st-century forest cover change. Science 342 (6160): 850-853. https://doi.org/10.1126/ science. 1244693

Hecht SB, Kandel S, Gomes I, Cuellar N, Rosa H (2006) Globalization, forest resurgence, and environmental politics in El Salvador. World Development 34 (2): 308-323. https://doi.org/10.1016/j. worlddev.2005.09.005

Hecht SB, Saatchi SS (2007) Globalization and forest resurgence: changes in forest cover in El Salvador. BioScience 57 (8): 663 672. https://doi.org/10.1641/B570806

Hernández C (2008) Dieta, uso de hábitat y patrones de actividad del Puma (Puma concolor) y el jaguar (Panthera onca) en la selva maya. Revista Mexicana de Mastozoología (Nueva Época) 12 (1) 113130. https://doi.org/10.22201/ie.20074484e.2008.12.1.48

Hunter L (2015) Wild cats of the world. Bloomsbury Publishing, London, $256 \mathrm{pp}$.

Knopff AA, Knopff KH, Boyce MS, St. Clair CC (2014) Flexible habitat selection by cougars in response to anthropogenic development. Biological Conservation 178: 136-145. https://doi.org/10. 1016/j.biocon.2014.07.017

Laundré JW, Hernández L (2010) What we know about pumas in Latin America? In: Hornocker M, Negri S (Eds) Cougar ecology and conservation. University of Chicago Press, Chicago, 76-90.

Linnaeus C (1771) Regni Animalis. Mantissa Plantarum 2: 266.

López-Carr D, Davis J, Jankowska MM, Grant L, López-Carr AC, Clark M (2012) Space versus place in complex human-natura systems: Spatial and multi-level models of tropical land use and cover change (LUCC) in Guatemala. Ecological Modelling 229: 64-75. https://doi.org/10.1016/j.ecolmodel.2011.08.020

Magg N, Müller J, Heibl C, Hackländer K, Wölfl S, Wölfl M, Bufka L, Červený J, Heurich M (2016) Habitat availability is not limiting the distribution of the Bohemian-Bavarian lynx Lynx lynx population. Oryx 50 (4): 742-752. https://doi.org/10.1017/S00 30605315000411

Marineros L, Martínez F (1998) Guía de campo de los mamíferos de Honduras. Instituto Nacional de Ambiente y Desarrollo, Tegucigalpa, $374 \mathrm{pp}$.

MARN (2018) Listado de inmuebles declarados como Área Natura
Protegida Ministerio de Medio Ambiente y Recursos Naturales de El Salvador, San Salvador, 8 pp. http://www.marn.gob.sv/ listado-de-areas-naturales-protegidas/. Accessed on: 2019-6-27.

MARN (2019) Areas de Conservación. http://www.marn.gob.sv/ areas-de-conservacion/06-27. Accessed on: 2019-10-19.

Monroy-Vilchis O, Gómez Y, Janczur M, Urios V (2009) Food niche of Puma concolor in central Mexico. Wildlife Biology 15 (1): 97 106. https://doi.org/10.2981/07-054

Moss WE, Alldredge MW, Logan KA, Pauli JN (2016) Human expansion precipitates niche expansion for an opportunistic apex predator (Puma concolor). Scientific Reports 6: 39639. https://doi. org/10.1038/srep39639

Nielsen C, Thompson D, Kelly M, Lopez-Gonzalez CA (2015) Puma concolor. The IUCN Red List of threatened species 2015: e.T18868A97216466. http://doi.org/10.2305/iucn.uk.2015-4.rlts.t1 8868a50663436.en. Accessed on: 2019-6-27.

Novack AJ, Main MB, Sunquist ME, Labisky RF (2005) Foraging ecology of jaguar (Panthera onca) and Puma (Puma concolor) in hunted and non-hunted sites within the Maya Biosphere Reserve, Guatemala. Journal of Zoology 267 (2): 167-178. https:// doi.org/10.1017/S0952836905007338

Núñez R, Miller B, Lindzey F (2000) Food habits of jaguars and pumas in Jalisco, Mexico. Journal of Zoology 252 (3): 373-379. https://doi.org/10.1111/j.1469-7998.2000.tb00632.x

Owen JG, Girón L (2012) Revised checklist and distributions of land mammals of El Salvador. Museum of Texas Tech University 310: $1-30$.

Polisar J, Maxit I, Scognamillo D, Farrell L, Sunquist ME, Eisenberg JF (2003) Jaguars, pumas, their prey base, and cattle ranching: Ecological interpretations of a management problem. Biological Conservation 109 (2): 297-310. https://doi.org/10.1016/S00063207(02)00157-X

Reid FA (2009) A field guide to the mammals of Central America and Southeast Mexico, Oxford University Press. New York, 346 pp.

da Silva LG, Cherem JJ, Kasper CB, Campos Trigo T, Eizirik E (2014) Mapping wild cat roadkills in southern Brazil: baseline data for species conservation. CATnews 61: 4-7. https://doi.org/10.13140/ RG.2.2.17640.88327

Soto-Shoender JR, Giuliano WM (2011) Predation on livestock by large carnivores in the tropical lowlands of Guatemala. Oryx 45 (4): 561-68. https://doi.org/10.1017/S0030605310001845

Sunquist ME, Sunquist F (2002) Wild cats of the world. University of Chicago Press, Chicago, 452 pp.

de la Torre JA, Núñez JM, Medellín RA (2017) Spatial requirements of jaguars and pumas in Southern Mexico. Mammalian Biology 84: 52-60. https://doi.org/10.1016/j.mambio.2017.01.006

UNESCO (2016) Trifinio Fraternidad (El Salvador/Guatemala/Honduras) http://www.unesco.org/new/en/natural-sciences/environment/ ecological-sciences/biosphere-reserves/latin-america-and-thecaribbean/el-salvadorguatemalahonduras/trifinio-fraternidad/. Accessed on: 2019-6-03.

USFWS (2014) Using road kill data to provide a panther population estimate with statistical confidence. https://www.fws.gov/ verobeach/FloridaPantherRIT.html. Accessed on: 2019-3-22.

Vreugdenhil D, Linares J, Komar O, Henríquez VE, Barraza JE, Machado M (2012) Mapa de los ecosistemas de El Salvador, Actualización 2012 con detección de cambios 1999-2011. World Institute for Conservation and Environment, Shepherdstown, 157 pp.

Winnie J Jr, Creel S (2017) The many effects of carnivores on their prey and their implications for trophic cascades, and ecosystem structure and function. Food Webs 12: 88-94. https://doi. org/10.1016/j.fooweb.2016.09.002

Zanin M, Palomares F, Brito D (2015) What we (don't) know about the effects of habitat loss and fragmentation on felids. Oryx 49 (1): 96-106. https://doi.org/10.1017/S0030605313001609 


\section{Appendix}

Summary of historical records of Puma concolor in El Salvador (Burt and Stirton 1961; Owen and Girón 2012) and their respective coordinates.

San Miguel, Olomega Lake (1942, voucher MVZ 98310): $13^{\circ} 17.79^{\prime} \mathrm{N}, 088^{\circ} 04.58^{\prime} \mathrm{W}$. Santa Ana, Montecristo National Park (1984): $14^{\circ} 24.04^{\prime} \mathrm{N}, 089^{\circ} 21.69^{\prime} \mathrm{W}$. Ahuachapán, El Imposible National Park (no date): $13^{\circ} 09.98^{\prime} \mathrm{N}, 089^{\circ} 58.00^{\prime} \mathrm{W}$. Cuscatlán, Guazapa Volcano (2000): $13^{\circ} 53.65^{\prime} \mathrm{N}, 089^{\circ} 06.53^{\prime} \mathrm{W}$. Morazán,
Cerro Cacahuatique (2000): $13^{\circ} 46.26^{\prime} \mathrm{N}, 088^{\circ} 11.70^{\prime} \mathrm{W}$. La Libertad, Walter Thilo Deininger Park (2002): $13^{\circ} 29.64^{\prime} \mathrm{N}, 089^{\circ} 15.75^{\prime} \mathrm{W}$. Chalatenango, El Manzano (2004): $14^{\circ} 11.77^{\prime} \mathrm{N}, 089^{\circ} 00.12^{\prime} \mathrm{W}$. Cabañas, ANP Bosque de Cinquera (2005): $13^{\circ} 52.97^{\prime} \mathrm{N}, 088^{\circ} 57.78^{\prime} \mathrm{W}$. Morazán, El Carrizal (2002): $13^{\circ} 57.42^{\prime} \mathrm{N}, 088^{\circ} 05.13^{\prime} \mathrm{W}$. Chalatenango, La Montañona (2006): $14^{\circ} 8.06^{\prime} \mathrm{N}, 088^{\circ}$ $54.82^{\prime} \mathrm{W}$. San Miguel, El Chaparral (no date): $13^{\circ}$ $51.47^{\prime} \mathrm{N}, 088^{\circ} 21.26^{\prime} \mathrm{W}$. 